Climate 



\title{
Before the discovery of the
} pre-salt layer resources: Greenhouse gas emissions from the oil and gas industry in Brazil ${ }^{1}$

\author{
THIAGO DE ARAÚJO MENDES \\ and SAULO RODRIGUES FILHO
}

\section{Introduction}

1 MONG THE various interactions between development and environment, the climate change-energy binomial is one of the most challenging issues of our time, for both science and policy. The nature of the global warming issue is different from that of any other political issue, because of either its future-oriented dimension or its scale (Giddens, 2009). According to the Intergovernmental Panel on Climate Change (IPCC, 1990, 1995, 200la, 2007a), greenhouse gas (GHG) emissions from the use of fossil fuels is the primary anthropogenic source that contributes to global warming. Solutions to mitigate climate change will entail both the systematic reduction of GHG emissions from the production and use of fossil fuels and the increasing use of renewable energy to generate a low-carbon economy (Stern, 2006; De Gouvello, 2010).

It is important to point out that the Brazilian energy matrix and GHG emissions are unique when compared to other countries in the international community, and especially when compared to the major economies of the PanAmerican continent. Unlike North American countries (such as Mexico and the United States), Brazil has a relatively low dependence on the use of fossil energy sources. According to the National Energy Balance (EPE, 2009), in 2008, 31.4 percent of domestic energy came from biomass (mainly sugar cane products, wood and charcoal) and 13.4 percent from water sources (hydroelectricity). Currently, Brazil is the second largest producer of ethanol in the world, and renewable energy sources represent about 45 percent of the national energy matrix (Brazil, 2010). Oil and its products account for about 36.7 percent of 
the total energy matrix, followed by natural gas with 10.3 percent and coal with 6.2 percent (53.2 percent come from fossil fuels), while 82 percent of the global energy matrix depends on fossil fuels (IEA, 2009). According to Brazil's Second National Communication to the United Nations Framework Convention on Climate Change (Brazil, 2010), in 2005 domestic GHG emissions reached about 2,192 million tons of $\mathrm{CO}_{2}$ equivalent. The land use, land use and change and forestry sector was responsible for about 61 percent of domestic $\mathrm{CO}_{2}$ emissions in 2005, while the energy sector accounted for about 15 percent of this total (Brazil, 2010).

However, due to the discovery of oil fields in the pre-salt layer and recent reductions in emissions from land use change in the Brazilian Amazon, the question is whether this proportion will change significantly and come, in the medium term, closer to the patterns of the economies of developed countries. Figure 1 illustrates the area where pre-salt reserves are located (in light gray). The oil province covering the pre-salt layer area is about $149,000 \mathrm{~km} 2$ long, stretching from the coast of Espírito Santo to the coast of Santa Catarina, and about $800 \mathrm{~km}$ long and $200 \mathrm{~km}$ wide in some areas (Lima, 2010; Azevedo, 2009; Lima, 2008). According to Azevedo (2009), about 28 percent of the province area - or $41,700 \mathrm{~km} 2$ - have already gone through the concession process.

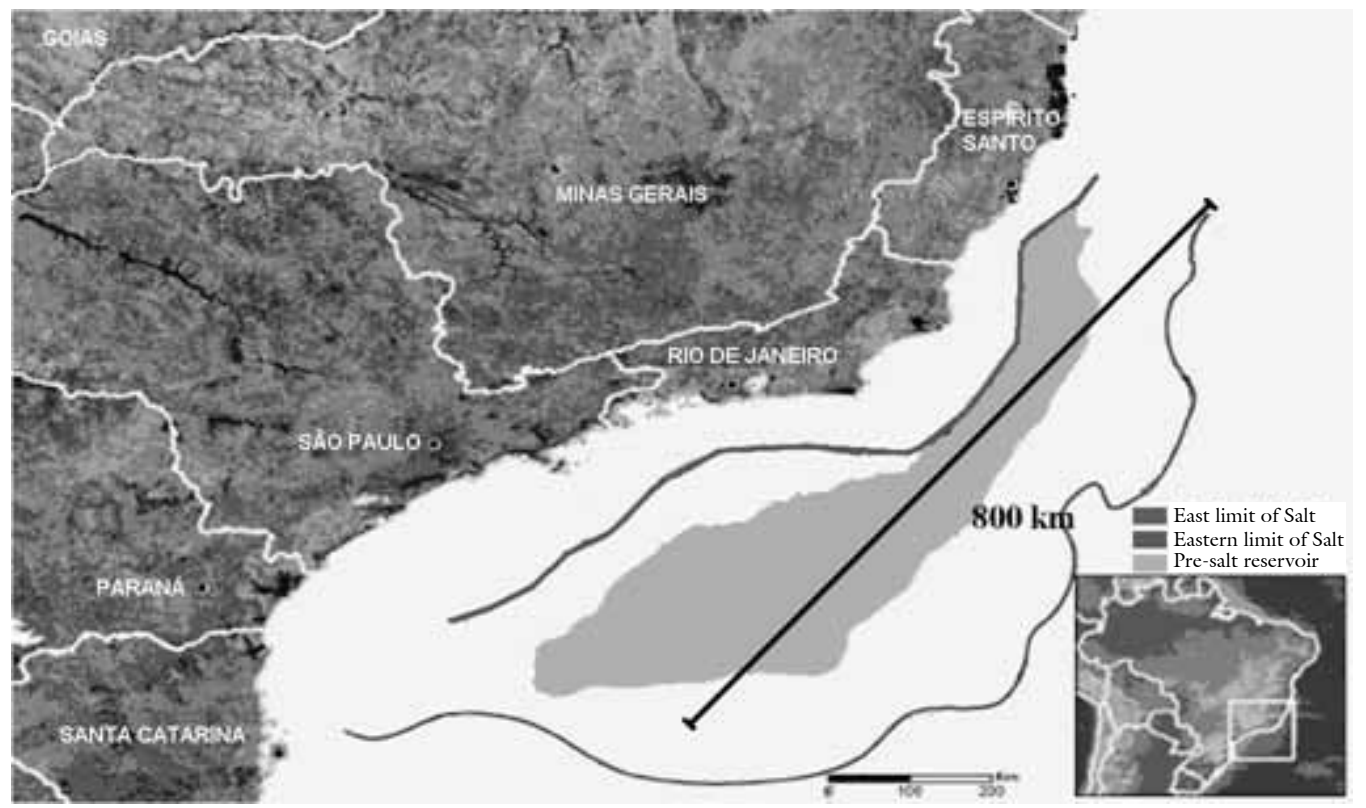

Source: Prepared from Nepomuceno (2008).

Figure 1 - Location of pre-salt reserves

According to Berman (2008), the three super-giant fields (above 500 million barrels of oil equivalent) identified in the region (Tupi, Jupiter and Carioca/ Pão de Açúcar) would add some 49 billion barrels of oil equivalent to Brazilian 
reserves. Comparatively, the National Agency of Petroleum and Biofuels (ANP) announced in 2006 that Brazil had about 11 billion barrels in proven reserves. If these reserves are confirmed, the country would move up from its current 15th place on the list of countries with the largest proven reserves in the world (CIA, 2012) and would more consistently join the group of ten countries with the largest number of proven reserves in the world, ahead of major producers such as Libya, Nigeria, Qatar and the United States.

Although many companies in the industry have technical capacity to explore oil in deep waters, no one deny the challenge facing Brazil to access, through Petrobras, these reserves, which lie more than 4,500 meters deep in the ocean. The "challenges facing this project $[\ldots]$ may come to play the role of catalysis of science, technology and innovation in Brazil, somewhat similar to the role the Apollo program - whose goal was to send humans to the Moon - played in the United States" (Becker et al., 2010, p. 50). The investment required for its operation would be about US\$400 billion, to be invested by 2020 (ibid, p.48-9). This investment will bring major implications for the socioeconomic conditions of Brazil (Lima, 2008) and will certainly draw international attention to the impact of these activities on the Brazilian energy matrix and on the GHG emission pattern.

The management and mitigation of GHG emissions arising from increased oil and natural gas production in Brazil, especially pre-salt layer reserves, because of their scale, can be considered one of the most challenging issues for the debate on sustainable development in Brazil between government, private sector, scientific institutions and civil society. Building a scientific foundation for the subject is relevant to assist in making present and future decisions about emission and mitigation management policies in this context.

This article seeks to contribute to debates about the sustainability analysis of the oil and gas industry in Brazil, aiming to identify the historical dynamics of fugitive emissions of greenhouse gases in the oil and natural gas industry in Brazil between 1990 and 2008. This limited time span is justified by the aim to systematize scientific data from the oil and gas industry in Brazil before the process of exploration, production and refining of hydrocarbons located under the pre-salt layer of Brazil's continental seabed. This systematization could serve as a basis for future assessments of the impacts of GHG emissions from pre-salt and define mitigation options for this sector in Brazil.

The analysis of fugitive emissions of greenhouse gases was built from the identification of various energy indicators and of the sector's socio-economic context, by examining secondary bibliographic data, including database publications produced by government and sectoral institutions. Among the materials consulted, special mention should be made of the time series of the national energy balance, data from the National Agency of Petroleum, Natural Gas and Biofuels and the reference reports used in the preparation of national greenhouse gas inventories. 
Thus, under the methodological scope adopted, this article does not aim to clarify issues related to the distinction between exploration and production models in their terrestrial and oceanic context (offshore exploration). It is clear that the Brazilian production is significantly higher in the off-shore environment (about 89 percent of total national E\&P activities occur in the marine environment). Likewise, it is not the focus of this article to analyze emissions relating to the use of products from oil and gas production in other sectors (e.g., the use of products in the transport sector) or to assess the trend of sustainability indicators and fugitive GHG emissions in the oil and gas industry for the coming years. However, the historical analysis of the indicators (the focus of this article) led to the construction of an interesting basis for prospective studies of future activities in the pre-salt region.

\section{Period and scope of analysis, factors and metrics applied}

The period under analysis - 1990 to 2008 - includes the first year of official monitoring by the Brazilian government of greenhouse gas emissions (1990) until the year prior to the actual beginning of prospecting procedures for the exploration of pre-salt resources. The scope of the analysis adopted limits fugitive emissions only to those linked to the three main greenhouse gases controlled by the United Nations Framework Convention on Climate Change (UNFCCC) namely $\mathrm{CO}_{2}$ (carbon dioxide), $\mathrm{CH} 4$ (methane) and $\mathrm{N} 2 \mathrm{O}$ (nitrous oxide). Data on GHG emissions at the stages of oil and gas exploration and production $(\mathrm{E} \& \mathrm{P})$, refining and transportation in Brazil were identified and analyzed. The data on total fugitive emissions apply the existing rules agreed under the Convention on Climate Change, thus adopting the global warming potential (GWP) approach.

Therefore, the following ratios were used for data on total fugitive emissions to be aggregated to the metric equivalent carbon dioxide $\left(\mathrm{CO}_{2} \mathrm{e}\right)$. For $\mathrm{N} 2 \mathrm{O}$, the value used was 310; for $\mathrm{CH} 4,21$; and for $\mathrm{CO}_{2}, 01$. The methodology that generated the data on emissions follows the parameters and requirements for calculating emissions set forth in the "Revised 1996 IPCC Guidelines for National Greenhouse Gas Inventories (Guidelines 1996)" and the "Good Practice Guidance and Uncertainty Management in National Greenhouse Gas Inventories (Good Practice Guidance 2000)" (Brazil, 2010, p.10). Examples of the fugitive emissions profile adopted using similar methods for the industry have been available in specialized publications since the early 1990s, in detailed emission inventories (Picard et al., 1992, UK Offshore Operators Association, 1993; U.S. EPA, 1993; OLF, 1993).

It is noteworthy that the concept of fugitive emissions associated with fuels, as used in this article, is the one adopted by the IPCC, which indicates whether these are intentional or unintentional releases of gases from human activities. In particular, they may arise from the production, processing, transport, storage and use of fuels, and include emissions from combustion only where these do 
not support a productive activity (e.g., combustion of natural gas at oil production facilities) (IPCC, 1996 p.1.6).

More specifically, in terms of fugitive emissions associated with the oil and gas industry (IPCC 1996), these emissions can be derived from disturbances and setbacks at any point in the production chain, exhaust leaks as well as equipment (non-combustion). Note, also, that combustion emissions are included when considered as a non-productive activity. Fugitive emissions from oil exploration; crude oil production; production, processing, collection and separation of natural gas systems; oil refining; storage; distribution of products; shipping and forwarding; loading and unloading of oil tankers; emissions from methane pipelines and local transportation; compressors and maintenance of facilities; ventilation; release and/or combustion of excess gases are also considered as fugitive emissions from this industry (IPCC, 1996 p.1.7) and will be addressed and grouped in this article into three major segments of the production chain: exploration \& production, transportation, and refining.

Likewise, the focus of the analysis for fugitive emissions from the oil and gas industry (the use of fuels in Brazil is not covered in this analysis) follows a consistent approach, so as to enable comparing dimensions and avoiding distortions in further analysis using the same database. According to the MME \& EPE (2010), due to future potential availability, it is estimated that in 2019 domestic daily consumption will be half the expected production for the industry, which is about 5.1 million barrels of oil per day.

The analysis of the relationship between total energy consumption and production in the oil and gas industry will adopt the ton of oil equivalent (toe) metric as a comparative energy unit. Analyses of the above mentioned indicators to Gross Domestic Product (GDP) and industry revenues are converted according to the 2007 annual average exchange rate of the U.S. dollar against the Brazilian real.

\section{Analysis of oil and gas industry indicators in Brazil}

The analysis of primary energy production by source in Brazil shows that oil and gas together accounted for about 48 percent of domestic primary energy production in 2008. Table 1 shows that between 1990 and 2008, the domestic supply of oil, oil products and gas in Brazil almost doubled from about 62 Mtoe to 118 Mtoe. A consistent reduction in imports by the industry (Oil, Natural Gas and Products) is observed in the period under study, representing a decline of about 9.5 Mtoe from 1990 to 2008, while domestic production increased more than threefold from 30.5 Mtoe in 1990 to 96.3 Mtoe in 2008. Therefore, exports by the industry grew by approximately 230 percent (from 4 Mtoe in 1990 to 13.3 Mtoe in 2008) and despite a more than two-fold increase in domestic consumption in the period (from 51 Mtoe in 1990 to 95 Mtoe in 2008), the so-called self-sufficiency (percentage of the aggregate domestic consumption of oil and natural gas products met by domestic production) has remained unchanged since 2005 . 
Table 1 - Evolution of domestic supply, imports, domestic production, exports, domestic consumption and percentage of domestic consumption met by domestic oil and gas production in Brazil

\begin{tabular}{|c|c|c|c|c|c|c|}
\hline Year & $\begin{array}{l}\text { Domestic } \\
\text { Supply (Oil, } \\
\text { Natural Gas } \\
\text { and Prod- } \\
\text { ucts) } \\
103 \text { toe }\end{array}$ & $\begin{array}{l}\text { Total industry } \\
\text { Imports (Oil, } \\
\text { Natural Gas } \\
\text { and Prod- } \\
\text { ucts) } \\
103 \text { toe }\end{array}$ & $\begin{array}{l}\text { Total domes- } \\
\text { tic produc- } \\
\text { tion of Oil, } \\
\text { Natural Gas } \\
\text { and Products } \\
\text { (Domestic } \\
\text { Industry) } \\
103 \text { toe }\end{array}$ & $\begin{array}{l}\text { Total Indus- } \\
\text { try Exports } \\
\text { (Oil, Natural } \\
\text { Gas and } \\
\text { Products) } \\
103 \text { toe }\end{array}$ & $\begin{array}{l}\text { Aggregate } \\
\text { Domestic } \\
\text { Consumption } \\
\text { (Oil, Natural } \\
\text { Gas and } \\
\text { Products) } \\
103 \text { toe }\end{array}$ & $\begin{array}{c}\text { Percentage } \\
\text { of Aggregate } \\
\text { Domestic } \\
\text { Consumption } \\
\text { (Oil, Natural Gas } \\
\text { and Products) } \\
\text { met by domestic } \\
\text { production (\%) }\end{array}$ \\
\hline 1990 & 62,085 & 31,510 & 30,575 & 4,075 & 51,014 & 59.93 \\
\hline 1991 & 62,252 & 30,767 & 31,485 & 3,788 & 51,799 & 60.78 \\
\hline 1992 & 64,201 & 31,827 & 32,374 & 4,070 & 53,283 & 60.76 \\
\hline 1993 & 66,632 & 35,711 & 30,921 & 3,383 & 55,637 & 55.58 \\
\hline 1994 & 70,387 & 34,948 & 35,439 & 2,737 & 58,162 & 60.93 \\
\hline 1995 & 76,210 & 33,958 & 42,252 & 1,359 & 63,151 & 66.91 \\
\hline 1996 & 81,796 & 38,958 & 42,838 & 724 & 68,714 & 62.34 \\
\hline 1997 & 87,228 & 41,124 & 46,104 & 2,328 & 73,353 & 62.85 \\
\hline 1998 & 91,263 & 40,982 & 50,281 & 5,042 & 75,608 & 66.50 \\
\hline 1999 & 93,229 & 36,455 & 56,774 & 5,232 & 75,811 & 74.89 \\
\hline 2000 & 96,999 & 33,716 & 63,283 & 6,849 & 77,835 & 81.30 \\
\hline 2001 & 100,523 & 32,553 & 67,970 & 9,352 & 79,421 & 85.58 \\
\hline 2002 & 100,176 & 23,469 & 76,707 & 10,044 & 80,695 & 95.06 \\
\hline 2003 & 96,580 & 18,141 & 78,439 & 11,008 & 79,233 & 99.00 \\
\hline 2004 & 102,708 & 26,434 & 76,274 & 12,082 & 82,624 & 92.31 \\
\hline 2005 & 105,079 & 19,301 & 85,779 & 11,108 & 84,390 & 101.65 \\
\hline 2006 & 107,261 & 17,760 & 89,500 & 13,223 & 86,331 & 103.67 \\
\hline 2007 & 111,438 & 19,603 & 91,834 & 11,790 & 91,084 & 100.82 \\
\hline 2008 & 118,344 & 22,031 & 96,313 & 13,297 & 95,184 & 101.19 \\
\hline
\end{tabular}

Source: Prepared by the authors from raw data provided by EPE (2009).

It should be pointed out that the data presented on the table above take into account the aggregate energy condition, that is, the quantities of tons of oil equivalent were added up for each energy source. Because of the availability of ethanol in the Brazilian fuel market and the nature of domestically produced oil (heavy oil), there is an overproduction of low-octane gasoline and crude oil in the domestic refining process, and an underproduction of diesel and natural gas among other products. Thus, export/import ratios are managed to meet the specific consumption demands of the Brazilian market for each oil and gas product required. Consequently, the self-sufficiency identified in terms of energy aggregates is not identified for the industry's trade balance (financial relationship between exports and imports), because the added value of exported products (e.g., crude oil) is lower than that of imported products (e.g., diesel). 
However, the national Gross Domestic Product (GDP) of the energy sector during the same period analyzed (1990-2008) also experienced a significant increase from about 45 billion to about 85 billion dollars. This significant GDP growth occurred especially from the turn of the millennium, after a downward trend throughout most of the 1990s. Another important datum to be examined is the relationship between the domestic supply of oil and oil products and GDP. In 1990, the ratio was 0.067 toe $/ \$ 1000$ of GDP. An assessment of the historical series for the period shows that the highest level was achieved in 1998 $(0.081$ toe $/ \$ 1000$ of GDP) followed by a steady downward trend that reached the lowest level in 2008 ( 0.059 toe / 1000 US \$ of GDP).

In terms of productive organization, it can be said that the oil and gas industry has an oligopolistic production profile. However, in comparative terms transport and distribution can be considered as more decentralized. In the oil sector, Petrobras has a captive and isolated role in some parts of the chain, but international giants (e.g. Chevron-Texaco and Shell) are also present in Brazil, as well as domestic companies such as OGX. The gas industry counts on the participation of state enterprises besides Petrobras (e.g., Gasmig, in Minas Gerais), thus enabling a slightly more decentralized regional distribution in relation to the oil sector. Moreover, the gas industry has an extensive retail network in terms of distribution for household use.

In terms of jobs created, Petrobras (2008) had approximately 67,000 employees. According to ONIP (2000), in 2000 the sector provided about 95,000 direct jobs, while the Federation of Oil Workers (FUP, 2010) indicated that it had over 150,000 members in 2010. The comparison of data (FUP, 2010; EPE, 2009; Brazil, 2010) enables inferring a ratio of about 1.3 jobs per 1,000 tons of oil equivalent, 2 based on a primary oil and gas production of about 115 Mtoe in 2008.

The analysis of greenhouse gas emissions shows that E\&P activities generated some 2.5 million tons of $\mathrm{CO}_{2}$ in 1990, against more than 7 million tons in 2008. This rise in GHG emissions represents an increase of about 191 percent in 2008 compared to 1990. These figures exceed the increase in the total domestic production of oil and natural gas, which over the same period rose about 215 percent (from 30.5 Mtoe in 1990 to 96.3 Mtoe in 2008).

The transportation stage of oil and natural gas produced in Brazil shows quite different figures. Although domestic production of natural gas, oil and oil products virtually more than tripled over the study period (1990-2008), fugitive emissions of GHG rose only 11 percent. Figure 1 shows the trajectory of emissions in this part of the chain between 1990 and 2008. Despite the significant growth recorded until 2005, an improvement and "efficiency growth" process implemented in the transportation area contributed to effectively reducing fugitive emissions in the sector, as seen in Figure 1. 


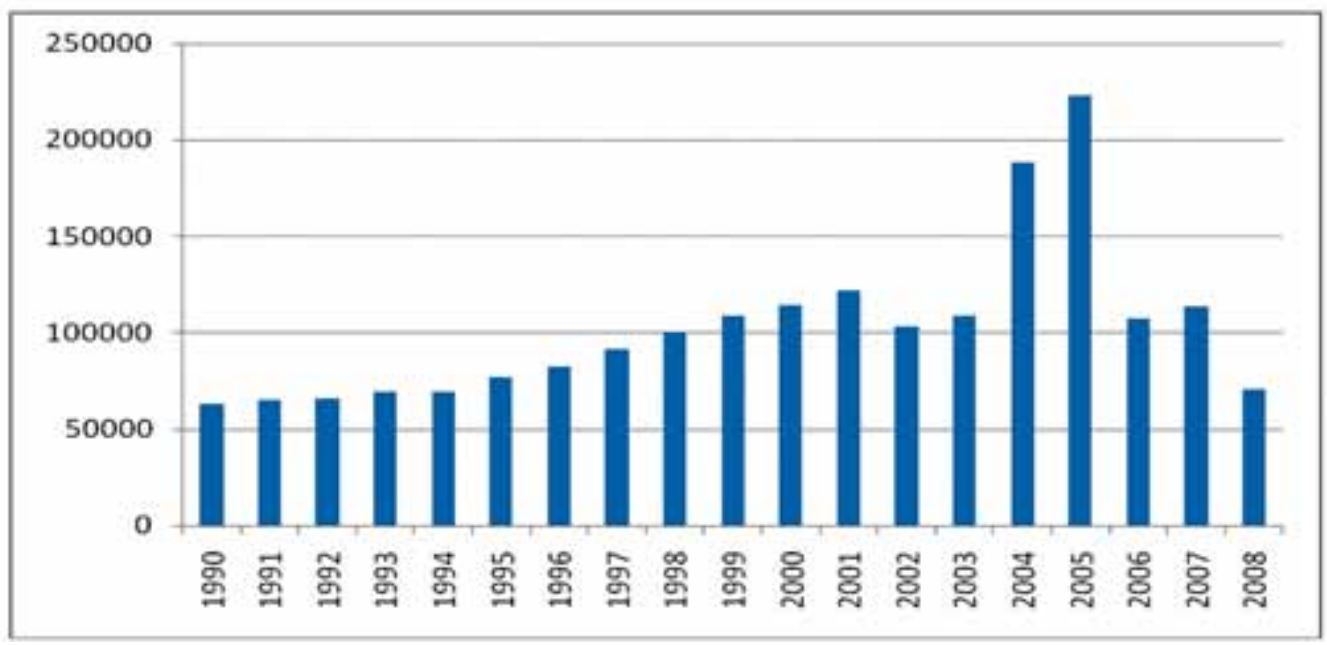

Source: Prepared by the authors from the MCT database (Brazil, 2010).

Figure 1 - Evolution of fugitive emissions of greenhouse gases $(\mathrm{tCO} 2 \mathrm{e})$ related to Oil and Gas transportation in Brazil from 1990 to 2008

The refining stage is the part of the supply chain that currently generates the largest amount of fugitive emissions of greenhouse gases. The volume of oil refined in Brazil increased considerably over the study period -53 percent $^{3}$ (EPE, 2009). Nevertheless, fugitive emissions of greenhouse gases in this part of the production chain were found to have risen above this level, showing an increase of 76 percent compared to 1990 (Brazil, 2010). Likewise, the comparison of data (EPE, 2009; Brazil, 2010) showed an increase of about 15 percent in fugitive emissions of GHG per unit of refined oil ( $\mathrm{tCO} 2 \mathrm{e} / \mathrm{toe})$.

Anyway, in a consolidated manner fugitive emissions of GHG from the oil and gas industry in Brazil correspond to about $15.3 \mathrm{MtCO}_{2} \mathrm{e}$ (Brazil, 2010), accounting for about 0.7 percent of Brazil's total emissions in 2005 (Brazil, 2010). Figure 2 shows that despite the peak of fugitive emissions of GHG during the E\&P phase in 2005, the refining stage is still responsible the highest absolute emission of GHG from the industry. 


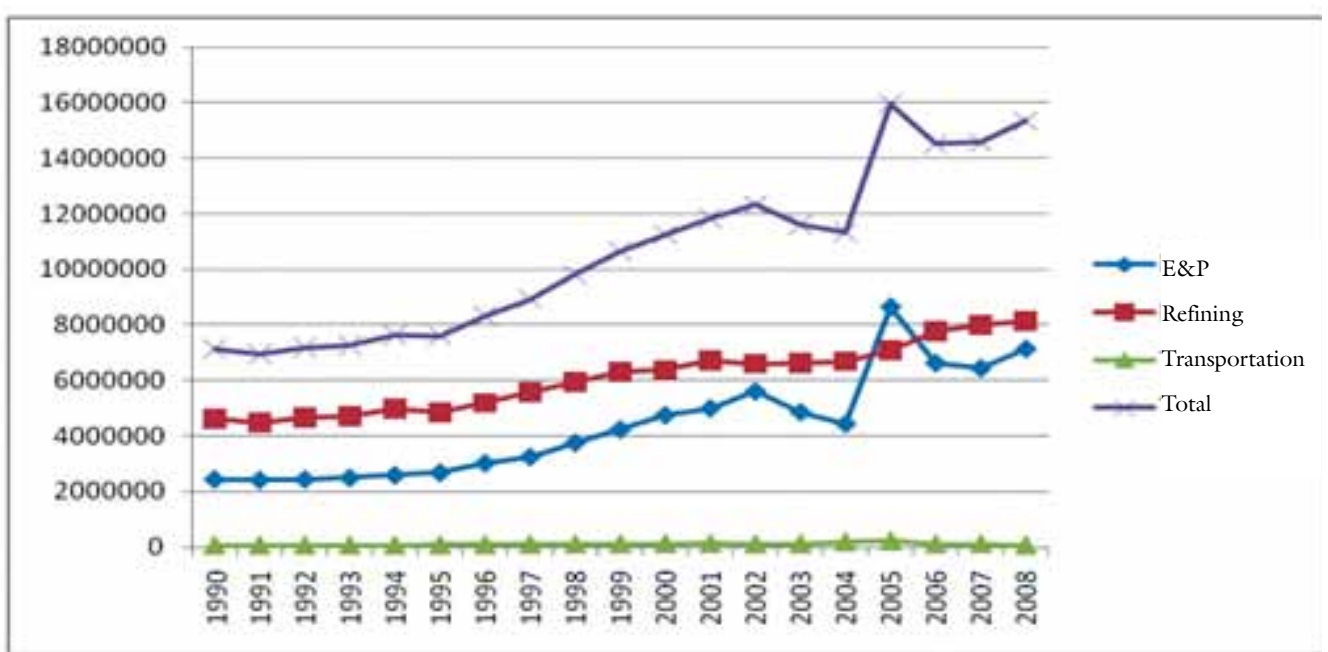

Source: Developed from the MCT database (Brazil, 2010).

Figure 2 - Evolution of total fugitive emissions of greenhouse gases in the oil and gas industry (tCO2e) in Brazil (1990-2008).

Table 2 enables comparing the evolution of GHG emissions from the domestic production of oil, oil products and natural gas. When considering the fugitive emissions from the three stages of the production process, a reduction was found in the relation of $\mathrm{kg} \mathrm{CO}_{2 \mathrm{e}}$ per primary toe produced over the study period, although absolute emissions almost doubled from 1990 to 2008. While in 2008 the relation was about $159 \mathrm{~kg} \mathrm{CO}_{2 \mathrm{e}} /$ toe domestically produced, in 1990 this figure was about $233 \mathrm{~kg} \mathrm{CO} 2 /$ toe. When this ratio is analyzed in percentage terms, a reduction of about 32 percent is found in the intensity of fugitive emissions from 1990 to 2008 per toe produced domestically.

In absolute terms, there was an increase in fugitive emissions from the sector of about 115 percent from 7.1 million tons of $\mathrm{CO}_{2} \mathrm{e}$ in 1990 to around 15.3 million tons of $\mathrm{CO}_{2} \mathrm{e}$ in 2008 . However, the magnitude of this increase is less than the growth of the total domestic production of oil, oil products and natural gas, which increased 215 percent from 30.5 Mtoe in 1990 to about 96.3 Mtoe in 2008. 
Table 2 - Evolution of domestic production, total fugitive emissions and ratio of $\mathrm{kg} \mathrm{CO}_{2} \mathrm{e} /$ domestic toe from the oil and gas industry in Brazil

\begin{tabular}{c|c|c|c}
\hline Year & $\begin{array}{c}\text { Total Domestic } \\
\text { Production of Oil, } \\
\text { Natural Gas and } \\
\text { Products }\end{array}$ & $\begin{array}{c}\text { Fugitive emissions } \\
\text { of } \mathrm{CO}_{2}, \mathrm{CH}_{4} \text { and } \\
\mathrm{N}_{2} \mathrm{O}\left(\mathrm{kgCO}_{2} \mathrm{e}\right)\end{array}$ & $\begin{array}{c}\text { Relation kg CO} \mathrm{e} / \\
\text { domestic toe }\end{array}$ \\
\hline 1990 & $30,575,136$ & $7,122,440,000$ & 233 \\
\hline 1991 & $31,484,794$ & $6,958,415,000$ & 221 \\
\hline 1992 & $32,373,999$ & $7,168,211,000$ & 221 \\
\hline 1993 & $30,921,236$ & $7,275,446,000$ & 235 \\
\hline 1994 & $35,439,143$ & $7,635,008,000$ & 215 \\
\hline 1995 & $42,251,632$ & $7,610,497,000$ & 180 \\
\hline 1996 & $42,838,494$ & $8,310,170,000$ & 194 \\
\hline 1997 & $46,104,389$ & $8,934,197,000$ & 194 \\
\hline 1998 & $50,281,174$ & $9,807,697,000$ & 195 \\
\hline 1999 & $56,774,229$ & $10,662,656,000$ & 188 \\
\hline 2000 & $63,282,503$ & $11,258,870,000$ & 178 \\
\hline 2001 & $67,970,457$ & $11,841,084,000$ & 174 \\
\hline 2002 & $76,707,161$ & $12,318,300,000$ & 161 \\
\hline 2003 & $78,438,957$ & $11,600,217,000$ & 148 \\
\hline 2004 & $76,273,864$ & $11,327,324,000$ & 149 \\
\hline 2005 & $85,778,541$ & $15,971,665,000$ & 186 \\
\hline 2006 & $89,500,312$ & $14,518,478,000$ & 162 \\
\hline 2007 & $91,834,184$ & $14,558,387,000$ & 159 \\
\hline 2008 & $96,313,328$ & $15,340,046,000$ & 159 \\
\hline
\end{tabular}

Source: Prepared by the authors from raw data provided by EPE (2009) and Brazil (2010).

\section{Final Remarks}

Energy consumption, production and supply, as well as GHG emissions can be considered relevant indicators for the analysis of sustainable development. The results found show a growth dynamics of fugitive emissions from the oil and natural gas industry in Brazil of about 115 percent in 1990 against annual emissions in 2008. In absolute terms, this increase in annual fugitive emissions from the industry was around 8.2 million tons of $\mathrm{CO}_{2 \mathrm{e}}$ when compared to 1990 and 2008. Although this increase is significant per se, when compared to the country's total emissions these emissions are still relatively low - less than 0.073 percent of domestic GHG emissions in 2005 .

However, the results obtained show that relevant fugitive emissions from the oil and gas industry in Brazil already existed before the pre-salt, and that the growth rate of these emissions increased in absolute terms (115\%) during the study period. It was also found that although the time horizon of the 
analysis is relatively short for the purpose of statistical analysis (18 years), there were positive developments in the period in terms of relative reduction of total GHG fugitive emissions in the sector per unit of domestic production. There was also a reduction from $233 \mathrm{~kg} \mathrm{CO}_{2 \mathrm{e}} /$ toe supplied in 1990 to $159 \mathrm{~kg} \mathrm{CO}_{2 \mathrm{e}}$ / toe supplied in 2008. This interpretation indicates that although the relative growth of absolute fugitive emissions occurred at a much slower pace than the domestic production of oil, oil products and natural gas, it is undeniable that the results clearly show that there is a growing relationship between the expansion of exploration and production activities and the increase in absolute emissions of greenhouse gases from the industry.

Therefore, it is still necessary to reflect on processes, policies and mechanisms that would propel the industry towards technological innovation, with the aim of addressing the challenge of reducing its GHG fugitive emissions in absolute terms. In this regard, mention should be made of the importance of conducting further prospective studies on employment indicators, energy consumption, as well as an analysis of the life cycle of GHG emissions from E\&P activities, refining and transportation of hydrocarbons from the pre-salt layer, as a contribution to the design of public policies and the development of preventive technologies. These reflections could help in the design of measures to reduce the environmental impact of the oil and gas industry, thus contributing to the realization of the sustainable development agenda in Brazil.

\section{Notes}

1 The authors thank Mr. José Domingos Gonzalez Miguez for his critical remarks during the drafting of this article.

2 Data from FUB (2010) were used, as they are considered conservative to represent the sector, since no precise data on occupation in the distribution sector within the production chain were found.

3 In 1990, Brazil refined 60,709,096 toes, while in 2008 this figure increased to $92,968,857$ toes.

\section{References}

ANP - NATIONAL PETROLEUM AGENCY. A nuário estatístico da Indústria do Petróleo 1990-1999. Rio de Janeiro: A Agência, 2000. Anuário Estatístico 2006. Available at: <http://www.anp.gov.br/conheca/anuario_2006.asp>. Access on 21 June 2007.

AUSTIN, D. et al. History of the offshore oil and gas industry in southern Louisiana: Interim report; Volume I: Papers on the evolving offshore industry. U.S. Dept. of the Interior, Minerals Management Service, Gulf of Mexico OCS Region, New Orleans, LA. OCS Study MMS 2004.

AZEVEDO, R. L. M. O Pré-sal: oportunidades para o Brasil. In: SIMPÓSIO DE GEOLOGIA DO SUDESTE. Estância de São Pedro, 17 October 2009.

BRAZIL - Ministry of Science and Technology (MCT). Emissões Fugitivas do Setor 
de Petróleo e Gás Natural. Relatórios de referência - versão para consulta pública. Segundo inventário nacional de gases de efeito estufa (GEE). Brasília: MCT, 2010.

BRAZIL. First National Communication Under the United Nations Framework Convention on Climate Change. Brasília: MRE/MCT/MMA/MME and MDIC, 2006.

A contribuição do Brasil para evitar a mudança do clima. Brasília: MRE/ $\mathrm{MCT} / \mathrm{MMA} / \mathrm{MME}$ and MDIC, 2007.

Ministry of Science and Technology. General Coordination of Global Climate Change. Second National Communication Under the United Nations Framework Convention on Climate Change. Brasília: MCT, 2010.

BECKER, B. et al. Livro azul da $4^{a}$ Conferência Nacional de Ciência e Tecnologia e inovação para o Desenvolvimento Sustentável. Brasília: Ministry of Science and Technology/Management and Strategic Studies Center, 2010.

BERMAN, A. Three super-giant fields discovered in Brazil's Santos Basin. World Oil, v.229, n.2, fev. 2008.

CASTRO, I. E. de. Geografia e politica. Rio de Janeiro: Bertrand Brasil, 2006.

CIA. The World Fact Book - Country Comparison: Oil - proved reserves. Available at: $<$ https://www.cia.gov/library/publications/the-world-factbook/rankorder/2178rank. html>. Access on: 7 Feb. 2012.

DE GOUVELLO, C. et al. Brazil Low-carbon Country Case study. Washington: The World Bank Group, 2010.

EPE - ENERGY RESEARCH COMPANY. Balanço energético nacional 2009 - Ano Base 2008. Rio de Janeiro: EPE, 2009.

FUP - GENERAL UNION OF OIL WORKERS. História da FuP. Available at: <http://www.fup.org.br/historia.php>. Access on: 5 Sept. 2010.

GIDDENS, A. The politics of climate change. Cambridge: Polity Press, 2009. IEA. World Energy Outlook. International Energy Agency, 2009.

IPCC - INTERGOVERNMENTAL PANEL ON CLIMATE CHANGE. First Assessment Report 1990. (FAR) WMO/UNEP, 1990.

IPCC. Second Assessment Report-Climate Change 1995: A report of the Intergovernmental Panel on Climate Change. Geneva: WMO/UNEP, 1995.

Unep, 1996.

. IPCC Guidelines for National Greenhouse Gas Inventories. Geneva: WMO/

. Third Assessment Report-Climate Change 2001 - and the Synthesis Report. Geneva: IPCC, 2001a.

IPCC - INTERGOVERNMENTAL PANEL ON CLIMATE CHANGE. Revised Good Practice Guidance and Uncertainty Management in National Greenhouse Gas Inventories. Good Practice Guidance 2000. Geneva: IPCC, 2001 b.

Fourth Assessment Report of the Intergovernmental Panel on Climate Change IPCC. Geneva: WMO/UNEP, 2007a.

. Guidelines for National Greenhouse Gas Inventories (2006 Guidelines) v.2

- Energy; v.3 - Industrial Processes; v.4-AFOLU. IGES for the IPCC. Tokyo, 2007b. 
Definitions and Methodological Options to Inventory Emissions from Direct Human-induced Degradation of Forests and Devegetation of Other Vegetation Types. IGES for the IPCC. s. d.

LENZEN, M.; DEY, C. Truncation error in embodied energy analyses of basic iron and steel products. Energy, v.25, Pergamon, 2000.

LIMA, J. A. M. A energia que vem do mar: a herança energética do mar brasileiro. Cienc. Cult. [online], v.62, n.3, p.25-8, 2010.

LIMA, P. C. R. Os desafios, os impactos e a gestão da exploração do pré-sal. Estudo. Brasília: Consultoria Legislativa, Nov. 2008.

LUHNOW, D. México criou o nacionalismo do petróleo e agora paga caro por isso. $O$ estado de S. Paulo/Wall Street Journal. 15 June 2005.

MEXICO. Tercera Comunicación Nacional ante la Convención Marco de las Naciones unidas sobre el Cambio Climático. Ciudad de México: INE, 2006.

MME \& EPE, Ministry of Mines and Energy, Energy Research Company. Plano Decenal de Expansão de Energia 2019 / Ministry of Mines and Energy. Energy Research Company. Brasília: MME/EPE, 2010.

NAKAMURA, S.; KONDO, Y. Input-Output Analysis of Waste Management. Journal of Industrial Ecology, Massachusetts Institute of Technology and Yale University, v.6, n.1, 2002.

NASAI, K. et al. Compilation and Application of Japanese Inventories for Energy Consumption and Air Pollutant Emissions Using Input-output Tables. Environmental Science and Technology, v.37, n.9, 2003.

NEPOMUCENO, F. Experiências da Petrobras no caminho do pré-sal. In: RIO OIL \& GAS CONFERENCE. Rio de Janeiro. September 2008.

OLF - Norwegian Oil Industry Association. Report from OLF Environmental Programme - Phase 2. Oslo: 1993

ONIP - NATIONAL ORGANIZATION OF THE OIL INDUSTRY. Impacto econô $\hat{o}^{-}$ mico da expansão da industria do petróleo - Final Report. December 2000.

PETROBRAS. Balanço Social e Ambiental 2008 - efetivo aumenta 52,1\% em cinco anos. Available at: <http://www.hotsitespetrobras.com.br/rao2008/il8n/pt/balanco-social-e-ambiental/trabalho/trabalhadores.aspx>. Access on 4 Sept. 2010.

PICARD, D. et al. A Detailed Inventory of $\mathrm{CH} 4$ and VOC Emissions from Upstream Oil and Gas Operations in Alberta. Clearstone Engineering Ltd., for the Canadian Petroleum Association, March 1992.

PICARD, D. et al. Fugitive Emissions from Oil and Natural Gas Activities: Background paper. In: IPCC, Energy Sector - Good Practice Guidance and Uuncertainty Management in National Greenhouse Gas Inventories. Revised Good Practice Guidance and Uncertainty Management in National Greenhouse Gas Inventories (Good Practice Guidance 2000). Geneva: IPCC, 2001.

PRESTE, P. Le. Ecopolitica internacional. São Paulo: Senac, 1997. 518p.

RITTER, K. et al. Consistency in Greenhouse Gas Emissions Estimation for Oil and Gas Industry Operations - A Non-Trivial Pursuit. American Petroleum Institute (API). S. d. 
STERN, N. et al. Stern Review on the Economics of Climate Change. London: HM Treasury, 2006.

UK Offshore Operators Association Ltd. Methane Emissions From Offshore Oil \& Gas Exploration \& Production Activities 1992. Submitted to The Watt Committee on Energy, 1993.

UNFCCC. Sixth compilation and synthesis of initial national communications from Parties not included in Annex I to the Convention. Montreal, SBI Twenty-ninth session. 1-10 December 2008.

US EPA. Anthropogenic Methane Emissions in the United States: Estimates for 1990, Report to the US Congress, US Environmental Protection Agency, Office of Air and Radiation, Washington, DC, USA, 1993.

USA. US Climate Action Report - Fourth National Communication of the United States of America Under the United Nations Framework Convention on Climate Change. Washington: USA, 2007.

WCED - WORLD COMMISSION ON ENVIRONMENT AND DEVELOPEMNT. Nosso futuro comum. 2.ed. Rio de Janeiro: Editora da Fundação Getulio Vargas, 1991.

ABSTRACT - The Brazilian Energy Matrix is known to be one of the most renewable in the world. Due to the size of the oil reserves found in the Pre-salt fields, doubts have been raised as to the maintenance of this energy and greenhouse gas (GHG) emission pattern. The scientific goal of this article is to identify the historical profile of the sector's fugitive GHG emissions due to the oil \& gas production, refining and transportation in Brazil from 1990 to 2008, prior to the Pre-salt layer hydrocarbon resources exploration. The study shows that total GHG emissions increased around 115 percent from 1990 to 2008 - an annual emission increase of 8.2 million $\mathrm{tCO}_{2}$. However, GHG intensity per ton of oil equivalent produced was reduced by 32 percent.

KErWORDS: Climate change, Oil and natural gas, Fugitive emissions of greenhouse gases, Pre-salt. 
Thiago de Araújo Mendes is a PhD candidate in Sustainable Development (CSDUNB) and a professor in the Graduate Program in Management of Environmental Projects at PUC Minas IEC-course Graduate Management Environmental Projects. @ - thiagomendes81@gmail.com

Saulo Rodrigues Filho holds a $\mathrm{PhD}$ in Environmental Sciences from the Universitat Heidelberg, Germany (1999, Magna Cum Laude) and is an associate professor and director of the Center for Sustainable Development (CDS) at the University of Brasilia (UNB). Deputy Editor of the Journal of Soils and Sediments - Springer. @ - saulofilhocds@gmail.com

Received on 14 March 2011 and accepted on 18 March 2011. 